\title{
The Reappropriation of Mythology to Represent Pain: Falling Silent in the Work of Kathy Acker and Robert Mapplethorpe
}

\author{
GEORGINA COLBY
}

In July 2005 the Solomon R. Guggenheim Museum in New York exhibited the show 'Robert Mapplethorpe and the Classical Tradition: Photographs and Mannerist Prints'. The project was organized by the Solomon R. Guggenheim Foundation in collaboration with the State Hermitage Museum, St. Petersburg. The show's comparative exploration of the dialogue between the photographer's work and classical art, specifically the late-sixteenth-century Flemish Mannerist prints, foregrounded Mapplethorpe's complex engagement with the classical body. This major exhibition gave breadth and emphasis to the longstanding critical observation of the importance of the relationship between Mapplethorpe's body of work and classical mythology.

Born in 1946 in Floral Park, Queens, Mapplethorpe enrolled at the Pratt Institute in Brooklyn in 1963 where he studied drawing, painting and sculpture. In 1970 he began producing Polaroid images in order to incorporate them into the collages he was making. He changed his Polaroid for a Hasselblad medium-format camera in 1976 and re-focussed his attention on portraiture. Despite its subject matter of homosexual sexual practices and sadomasochism, which was labelled obscene by the cultural norms of American society in the period, whilst at the same time gaining the young photographer instant notoriety, Mapplethorpe's work became critically acclaimed throughout the art world. Germano Celant, a prominent art critic and Senior Curator of the Guggenheim Museum, was the first to comment on the 'linguistic specificity' of what he termed Mapplethorpe's 'Neo-Classical Photography'. ${ }^{\mathrm{I}}$ Ascribing a material role to the image and viewing the photographer's lens as the artist's clay, Mapplethorpe described photography as 'the perfect way to make a sculpture'. ${ }^{2}$ His sculptural photographic depictions of the 
human body conflate photography and sculpture in a way that produces a dialectical discourse between the two forms of art. Mapplethorpe can at once be read as appropriating and desublimating the classical forms of the Dutch Mannerist artists, working in the latter part of the Italian High Renaissance around $\mathrm{I}_{520}$ and into the seventeenth century, such as Henrick Goltzius, Jan Hermensz, Jacob Matham and Jan Saenredam and, at the same time, elevating the contemporary photograph to the status of classical art, in Celant's words, '[wedding] photography and art in a rigorous, classical language'. ${ }^{3}$

Mapplethorpe's engagement with classical mythology has a literary counterpart in the work of experimental writer, essayist and performance artist Kathy Acker. Acker, born in New York in 1947, just one year after Mapplethorpe, shared the same cultural milieu. Contemporaries that they were, both Acker and Mapplethorpe were part of the artists' and writers' community of Manhattan's Lower East Side in the I970s and I98os. Indebted to the Black Mountain poets, in particular Charles Olson and later to the process writing of her mentor David Antin, Acker's innovative writing crosses avant-gardism with the subcultural elements of the Lower East Side art world in which she lived and worked.

Both Acker and Mapplethorpe began working in the I970s, the decade that witnessed the explosion of punk and gay cultures. They address the socio-political factors of living on the fringe of a conservative society, which over the period in which they worked and lived saw a succession of three Republican presidents in Nixon, Reagan and (for Acker) Bush. Acker and Mapplethorpe were by no means strangers to one another. Mapplethorpe photographed Acker in I983, while Acker wrote the 'Introduction' for Mapplethorpe's collaboration with the Belgian multidisciplinary artist Jan Fabre, The Power of Theatrical Madness, in 1986. Read comparatively, the works of Acker and Mapplethorpe illustrate complementary ways in which the radical writer and the radical artist recontextualize the body of antiquity within a modern avant-garde framework for new radical purposes. Their works can be viewed in terms of the 'neo-avant-garde', defined by Hal Foster as 'art since 1960 that refashions avant-garde devices [...] to contemporary ends' ${ }^{4}$ In his critical re-evaluation of the avant-garde in 1996, Foster views the neo-avant-garde as 'repositioning art in relation to social practice', thereby offering 'a crucial coarticulation of artistic and political forms'. ${ }^{5}$ Acker and Mapplethorpe's earlier compositions tend towards a celebration of eroticism and sexual diversity and a challenge to the cultural restraints of society. In the representation of radical themes 
both Acker and Mapplethorpe address the problematics of representing aspects of culture that are prohibited, if not legally then anathematized and censored by the conventional aesthetic of the prevailing culture at the time. In a very important sense, in disclosing such aspects, Acker and Mapplethorpe aim to transgress a politically imposed inexpressibility.

More specifically for our purposes here, both writer and photographer, in their later work, re-evaluate mythology to represent pain. The transgression of political inexpressibility in Acker's and Mapplethorpe's early works in many ways facilitates their transcendence of the inexpressibility of pain in their later works. Elaine Scarry in her study The Body in Pain: The Making and Unmaking of the World (I985) divides the single subject of bodily pain into three different subjects: 'first, the difficulty of expressing physical pain; second, the political and perceptual complications that arise as a result of that difficulty; and third, the nature of both material and verbal expressibility, or, more simply, the nature of human creation'. ${ }^{6}$ Reading Acker and Mapplethorpe through Scarry's study brings to light how photographer and writer address these three problematics of the representation of pain in their reclaiming of mythology. Crucially, Scarry acknowledges the topological relationship between these three subjects when she states '[p]hysical pain has no voice, but when it at last finds a voice, it begins to tell a story, and the story that it tells is about the inseparability of these three subjects, their embeddedness within one another'. ${ }^{7}$ It is through the reinscription of the body of classical mythology into the contemporary text and image in Acker's and Mapplethorpe's works that this narrative of pain finds a voice.

\section{REAPPROPRIATIVE TECHNIQUES}

Acker's and Mapplethorpe's works open up a discursive realm in which an interplay of the text, photograph and classical mythology takes place. My contention is that both Acker and Mapplethorpe programmatically aim to expose the limitations of their respective forms within latetwentieth-century American culture and can thus be read as producing, in their work, text and image respectively, what Acker calls a 'language of the body'. This is at once a language of self-expression and, owing to its ability to express the self, a language that enables the expression of radical subcultural elements. In their artistic and literary practices, the production of this language is contingent upon their reabsorbing mythological formations. Mapplethorpe's approach to the photograph as sculpture reveals a method of appropriation that can be compared with 
Acker's linguistic conception of language as bodybuilding. In Acker's and Mapplethorpe's works we find a shared use of the materiality of their representative form to reinscribe the classical body. In her essay 'Against Ordinary Language: The Language of the Body' (I993), Acker details her failure to write about bodybuilding and theorizes the relationship between this failure and the emergence of 'the language of the body' which 'resists ordinary language'. ${ }^{8}$ This resistance of the body to ordinary language in the act of bodybuilding possesses a parallel in Scarry's assertion that 'ordinarily there is no language for pain $[\ldots]$ it (more than any other phenomenon) resists verbal objectification'. ${ }^{9}$ In both Acker's and Mapplethorpe's representations of subcultural elements and Scarry's understanding of the inexpressibility of pain we can detect a paradox of representation by which elements are unveiled that resist ordinary language, and thus resist cultural expressibility.

Acker met this paradox in a writing experiment, an essay on bodybuilding. Her plan was to attend the gym (Acker herself was a bodybuilder) and then to describe everything she had experienced after each workout in a series of diary entries. This, she believed, would 'provide the raw material' for the essay. However, recognizing the failure of her method she stated "[a]fter each workout, I forgot to write. Repeatedly. I ... some part of me ... the part of "I" who bodybuilds ... was rejecting language, any verbal description of the language of bodybuilding'. ${ }^{\text {Io }}$ During the course of her experiment, Acker realized that the only way she could conceive of writing about bodybuilding was by 'analyzing this rejection of ordinary or verbal language'. ${ }^{I I}$ The act of bodybuilding has an affinity with both Acker's own literary practice of appropriation and Mapplethorpe's appropriative sculptural praxis. Bodybuilding, Acker writes, 'is a process [...] by which a person shapes his or her own body. $[\ldots]$ The general law behind body-building [sic] is that muscle, if broken down in a controlled fashion and then provided with the proper growth factors such as nutrients and rest, will grow back larger than before'. ${ }^{12}$ Once she had recognized muscular destruction in bodybuilding as vital to muscular growth, she was able to analogize her experience to art, asking: 'Is the equation between destruction and growth also a formula for art?' 3

In Acker's own work this destruction-growth formula becomes immediately apparent in both her feminist revisions of male texts and in her use of repetition within those texts. For instance, she takes the frames of texts such as Cervantes's picaresque novel Don Quixote (I605) and Dickens' Great Expectations (I86I) only to repeat them within her experimental appropriations. Retaining the notion of Don Quixote's 
chivalrous quest, Acker requisitions Cervantes's punning and verbal playfulness and inserts it into her own feminist satire, Don Quixote: Which Was a Dream (I986), in which she attacks those she perceives as the cultural and political reactionaries of the United States. With Acker's Don Quixote being female, it is perhaps not surprising to find the novel beginning in an abortion clinic; indeed, in the first chapter of her novel 'having an abortion is a method of becoming a knight and thus saving the world'. ${ }^{14}$ The 'pale or puke green paper'"5 Don Quixote wears is her armour. Echoing Cervantes's delusional narrator's request to the innkeeper to dub him a knight, Acker's female Don Quixote, punning on medical instruments, decides 'catheter' is the glorification of 'Kathy' and '[b]y taking on such a name which, being long, is male, she would be able to become a female knight or a night-knight'. ${ }^{16}$ This technique, which effects a distortion, repetition and consequent fracture of classic male texts, facilitates Acker's displacement of traditional narrative structure and imbues her novels with new radical connotations.

This method of feminist appropriation is repeated in microcosm within the body of Acker's recontextualizations. The symbolic confinement of conventional syntax is aligned with institutional oppression. Acker uses repetition to strip syntax of meaning. She does this in her earliest work, Blood and Guts in High School (1976), in Janey's Persian poems. 'The Persian Poems' are a series of grammar exercises that through repetition expose the constraints of language that educational institutions impose. Janey's desire to rid herself of the semiological structure is paradoxical as it takes the form of drilling a verb structure 'to get rid of language'. ${ }^{17}$ Janey, in these constructions, refers to herself in the third person: there is no ' $\mathrm{I}$ '. Her desire to move beyond language is disempowered by the very means through which she expresses that desire. Conventional language in Acker's work is imprisoning. Breaking the confines of that language, her work embodies a movement both towards death and myth, and towards a liberation of the self: 'the closer we are living to total human death', one of Acker's female voices states, 'the weaker the socio-political restraints on us'. ${ }^{18}$

Acker then views the world of mythology as antithetical to the suppression of the individual under capitalism. The consequence of political and cultural oppression is the turning of the individual away from a dead reality toward myth, which Acker understands as a new reality. Acker's earlier texts such as Blood and Guts in High School, in which her female protagonists are trapped within the confines of sociopolitical constraints, are precursors to her later texts such as Pussy, King 
of the Pirates (1996) whereby her protagonists find a language for the self and escape repression through recourse to mythology. In her brief introduction to Fabre and Mapplethorpe's collaboration The Power of Theatrical Madness, entitled 'Opera: The Actual Working of Terror and Ecstasy', she writes:

Confronted with an exorbitant unapproachable that casts its alien shadow over him, the individual feels an affinity with the world of myth. What he shares with it is the gesture of falling silent. Not only the inability but also the refusal to believe in or speak the truth, the recourse to myth which turns a theatrical or communicatory gesture into opera is a phenomenon of the world in which there is cause to fear everything. ${ }^{\mathrm{I} 9}$

Mythology in Acker's works such as Don Quixote is associated with the double motif night/knight, that which escapes the fear induced by cultural censorship. Yet, as this passage shows, Acker also apprehends myth as a sublimating force. The use of mythology enables Acker to find a language for feminine subjectivity and for desire that exceeds and invalidates conventional cultural tropisms of identity.

Take the case of Pussycat and the pirates in Pussy, King of the Pirates. As well as Pussycat being an unknown and ephemeral Eurydice figure ('She disappeared as fast as she had come') ${ }^{20}$, Acker's prostitutes/pirate girls are a punk appropriation of Ovid's Propoetides. Book X of Ovid's Metamorphoses tells the story of the 'loathsome Propoetides'; as a result of their denial of the divinity of Venus, 'they were visited by the wrath of the goddess, and were the first women to lose their good names by prostituting themselves in public'. Then, 'as all sense of shame left them, the blood hardened in their cheeks, and it required only a slight alteration to transform them into stony flints' ${ }^{21}$ Acker restores the corporeality of the Propoetides in her appropriation of Ovid's myth. The pirate girls in Pussy 'wore their insides on their outsides, blood smeared all over the surfaces'. ${ }^{22}$ The pirate girls represent all that the male has suppressed in the female and all that a reactionary society fears in female sexual corporality: menstrual blood, discharge, odour and an active female desire as opposed to sexual passivity. In her reappropriation of mythology 'the many faults which nature has implanted in the female $\operatorname{sex}^{23}$ that Pygmalion was so revolted by when he encountered the Propoetides are the very elements that construct Acker's pirates and become the building blocks of a radical female agency.

The destruction-growth equation is also apparent in Mapplethorpe's method of recontextualization. Appropriating the classical tradition 
means reiterating its forms through repetition. In Mapplethorpe's work repetition occurs on two levels. Firstly, he repeats images and bodily configurations within the context of art history and in doing so corporealizes the clay of classical statues. In his essay 'The Satyr and the Nymph: Robert Mapplethorpe and His Photography' ${ }^{24}$ Germano Celant provides numerous examples of Mapplethorpe's appropriative technique. The breadth and scope of Mapplethorpe's references are extensive, ranging from the Neoclassicism of Jacques-Louis David's Marat assassiné (I 793) in his photograph fames Ford (I979) ${ }^{25}$ to the echoes of Man Ray's Surrealist Érotique violée (1933) in his portrait Bruce Thompson (1980). Perhaps two of the most significant examples of Mapplethorpe's technique of repetition within a historical line are his four portraits Ajitto (I98I) and his series of four plates entitled Thomas (1987). Ajitto, as Celant shows, has three historical antecedents: Hippolyte-Jean Flandrin's feune homme $n u$ assis au bord de la mer (I 855$),{ }^{26}$ Wilhelm Von Gloeden's 'Caino' (Male Nude Seated on a Rock) (1902) ${ }^{27}$ and Andy Warhol's charcoal drawing from a series of elaborations of photographs by Baron von Gloeden, Hommage to Wilhelm von Gloeden (1978). ${ }^{28}$ Within this framework the classical male nude undergoes a series of transformations. Flandrin's first nude is a painting of a white man sitting on a cloth on a rock by the sea. Von Gloeden appropriates Flandrin's nude in his photographic image of a Mediterranean man sitting on a rock against a wild landscape. Warhol's charcoal drawing divests the figure of solidity and three-dimensionality producing just a black outline of the figure on a white background.

Mapplethorpe's Ajitto reinstates the body but divests the background dislocating the male nude from the landscape, positioning him instead on a small draped table. This technique reinstates the classical image but also decontextualizes the image by setting the body against a blank background. He takes a further three photographs of Ajitto from different angles highlighting the three-dimensionality of Ajitto as a human sculpture. This method resists the human body becoming two-dimensional under the photographer's lens, at once restoring the body and crossing disciplines with his lens into the art of sculpture. In Mapplethorpe's appropriation the body is further given primacy as the dimensions of the table are smaller than the dimensions of the body and unlike the former images the male sexual organs are not hidden.

Acker states that part of the technique in breaking down a muscle group in bodybuilding is 'to make that group work up to, even beyond, capacity'. To do this Acker explains that it is necessary to 'visualize the part of the body that is involved. Mind and thought [...] [are] always 


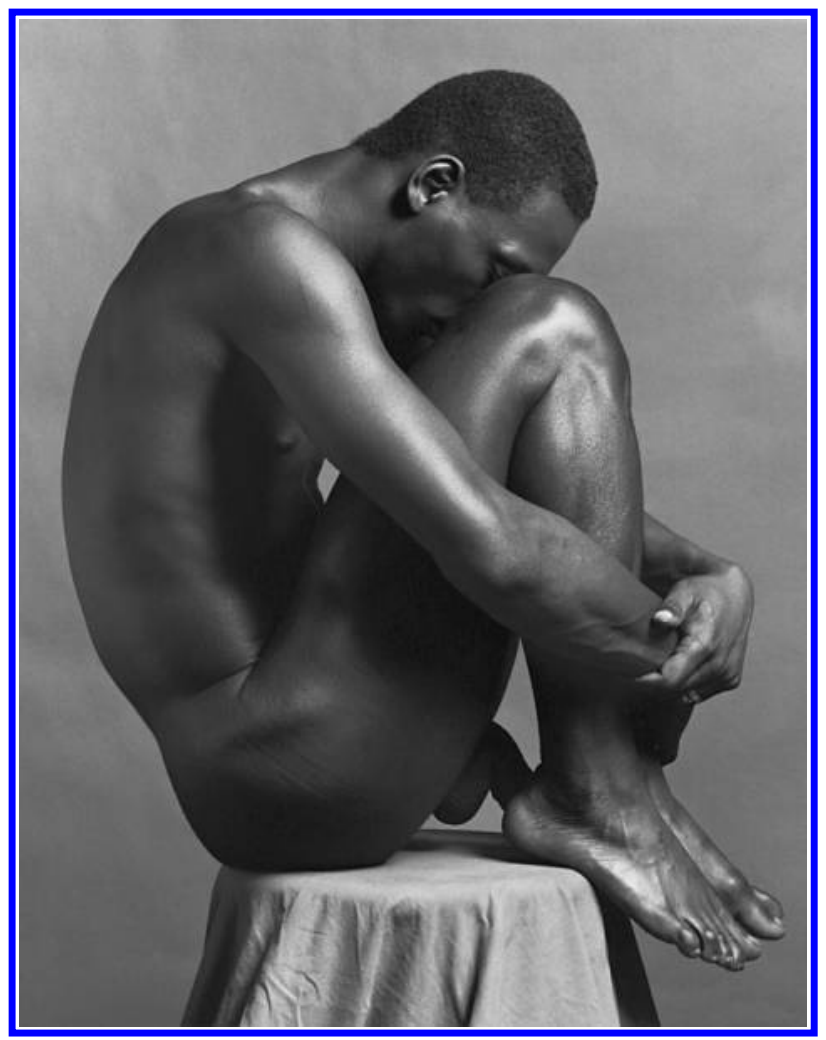

Figure I. Mapplethorpe, Ajitto, I98г. (C) Robert Mapplethorpe Foundation. Used by permission.

focussed on number or counting and often precise visualizations'. ${ }^{29}$ In Mapplethorpe's Ajitto we have a failure to replicate despite what can be read as 'precise visualizations' ${ }^{30}$ of the classical image. This distinction between repetition and replication is important. Whilst Mapplethorpe can be seen to be repeating the bodily configuration of the male nude in these photographs, the image is not an exact copy of the original. This failure to replicate is comparable to Acker's description of the process of breaking down muscle in bodybuilding in order to allow the growth of new larger muscle:

Bodybuilding can be seen to be about nothing but failure. A bodybuilder is always working around failure. Either I work an isolated muscle mass, for instance one of the tricep heads, up to failure. In order to do this, I exert the muscle group almost to the point that it can no longer move. 
But if I work the same muscle group to the point that it can no longer move, I must move it through failure. I am then doing what I call 'negative reps', working the muscle group beyond its power to move. Here is the second method of working with failure. $3^{\mathrm{I}}$

A visual and linguistic space is opened up in Acker's and Mapplethorpe's appropriations of mythology between the act of repetition and the failure of replication. Acker enacts this process in her repetition of the frame of male texts as well as her repetition of classical myths. Similarly, in repeating the precise visualization of the classical image within a contemporary context Mapplethorpe can be read as moving the image through the failure of replication. In the visual and linguistic elliptical spaces that are created in this process avant-garde cultural elements emerge within a neoclassical context. In this way, through the controlled repetition of the sculptured physique of the male nude in photography, within a classical framework, Mapplethorpe enacts an appropriative method comparable to Acker's bodybuilding.

Secondly, repetition takes place within Mapplethorpe's own body of work. The repetition of the classical body in Mapplethorpe's work performs a cross-gendering reappropriation of the classical image found in the work of Mannerist painters such as Matham's Apollo and the nineteenth-century sculptures of Auguste Rodin. This is shown in his photographs of Lisa Lyon and Derrick Cross.

Mapplethorpe covers Lisa Lyon in clay, a technique that implies a dehumanizing of the human body (Pygmalion). However, the clay is cracking and her pubic hair is visible highlighting the living body beneath the clay. Derrick Cross's body by contrast is cross-gendered. Though the contours of his hips and his thighs are highlighted in a stereotypically feminine way his body still remains visibly male. Male and female in this image are brought together in sculptured harmony, which resists gender distinctions and produces a new radical sexual aesthetic within the visualization of the classical bronze statue. In these images Mapplethorpe's technique creates a new language within his appropriations, giving voice in his early work to sexual and racial diversity.

The emergence in the work of art of this language that conflates meaning and essence is comparable to Acker's language of the body that she reads as being produced in the act of bodybuilding. It contrasts with and indeed rejects ordinary language. Commenting on the antithesis between meaning and essence that Wittgenstein unfolds at the end of his Tractatus Logico-Philosophicus, Acker asks: 'If ordinary language 


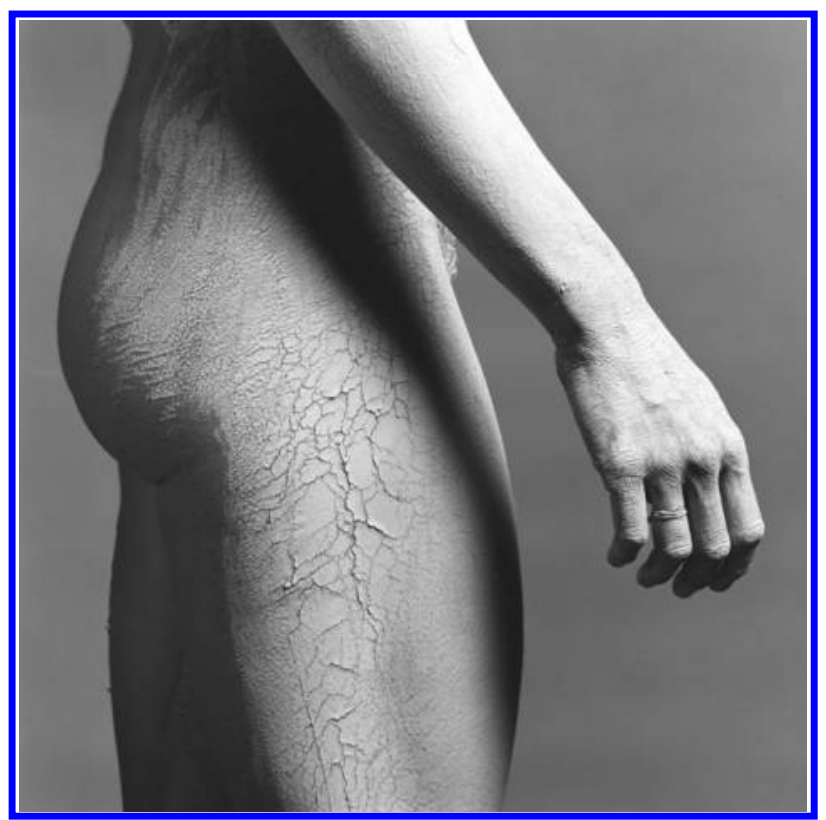

Figure 2. Lisa Lyon, I982. (C) Robert Mapplethorpe Foundation. Used by permission.

or meanings lie outside essence, what is the position of that language game which I have named the language of the body?' 'Bodybuilding', Acker conceives as being a language of the body, which at once 'rejects ordinary language' yet 'itself constitutes a language, a method for understanding and controlling the physical which in this case is also the self.$^{32}$ Acker recalls the Bulgarian-born but German-language novelist Elias Canetti's description of the beggars of Marrakech 'who possess a similar and even simpler language game: they repeat the name of God. In ordinary language', Acker argues, 'meaning is contextual. Whereas the cry of the beggar means nothing other than what it is; in the city of the beggar, the impossible (as the Wittgenstein of the Tractatus and Heidegger see it) occurs in that meaning and breath become one'. Acker claims that this is the site of the language of the body 'in which meaning and essence no longer oppose each other'. ${ }^{33}$ Acker's and Mapplethorpe's decontextualizing of classical mythology by repeating the configurations of mythology within a new subcultural contemporary context provides the conditions for the emergence of the language of the body, as it is through their acts of recontextualization that meaning and essence are conflated. This technique of appropriation in Acker's and 


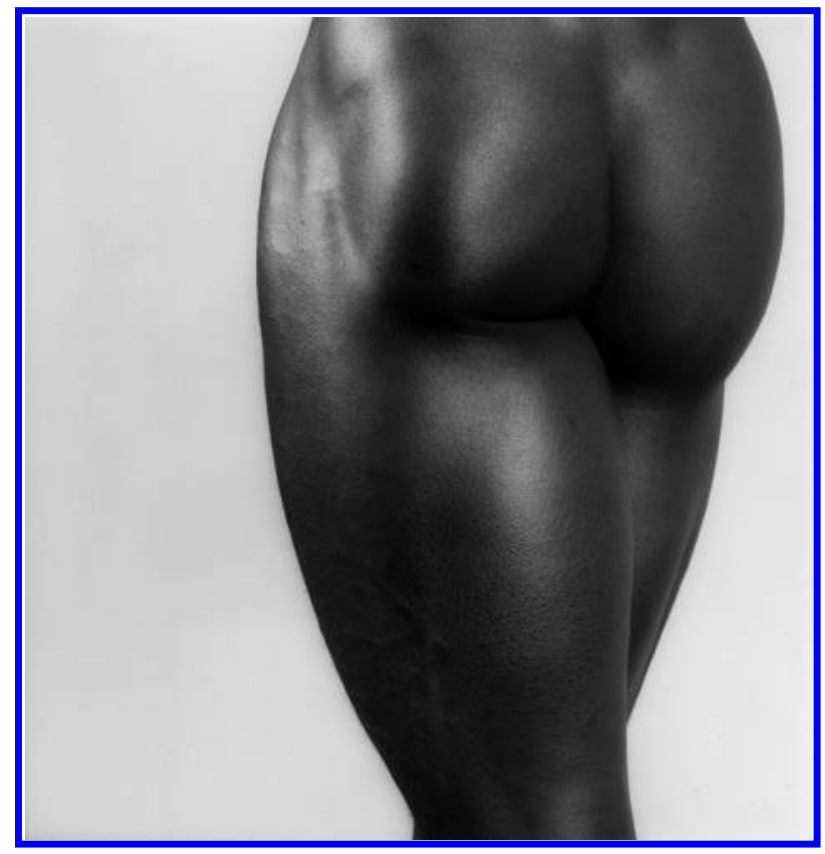

Figure 3. Derrick Cross, I983. (C) Robert Mapplethorpe Foundation. Used by permission.

Mapplethorpe's earlier work foregrounds the production of the silent languages of the body, which in their later work give voice to pain and death.

\section{FALLING SILENT}

In both Acker's and Mapplethorpe's bodies of work there is a distinct break between their earlier and later work. In their later work Acker addresses her breast cancer, Mapplethorpe addresses AIDS. Both Acker and Mapplethorpe represent in their later work a movement into a representational space that is not external but simultaneously is not the space of corporeality and desire that they portrayed in their earlier work. Instead, this space is explicitly mythological and is bound both to their placelessness in American society and the unrepresentability of pain. In their later work they reappropriate mythology back into classic mythological structures of representation. Acker's narrative structure in Eurydice in the Undermorld and Requiem is based on the Greek tragedy. 
When the naked body appears in Mapplethorpe's later work it tends to be a clay or marble statue or bust. As I will show in the final part of my argument, the effect of Mapplethorpe's repetition of the classical body through the photographing of clay and marble body artefacts against minimalist backgrounds is to detach and isolate the classical body, disinheriting the neoclassical body of his earlier work of its corporeality, whilst keeping it isolated within a contemporary framework.

The representation of ulterior space through the reappropriation of mythology in Acker's and Mapplethorpe's later work is a performative act that ultimately enables the representation of pain. In her chapter 'Pain and Imagining', Elaine Scarry attends to the idea of the world's construction and reconstruction through the relation between physical pain and imagining. In the first part of her study, Scarry looks at the infliction of pain in torture and war and this involves what she theorizes as the 'unmaking' of the world. She states that 'it is impossible to speak of either torture or war without attending to the destruction of the artefacts of civilization in either their interior and mental or exterior and materialised forms' ${ }^{34}$ More significantly, Scarry states that 'the infliction of pain in torture is inextricably bound up with a political "fiction" just as the injuries of war are bound up with a process of conferring facticity on unanchored cultural "constructs"'. Scarry reinstates her point that 'physical pain is exceptional in the whole fabric of psychic, somatic, and perceptual states for being the only one that has no object' in the external world. For Scarry, the only state that is as anomalous as pain is the imagination. Pain is remarkable owing to the fact that it has no object whereas imagination is remarkable, according to Scarry, on account of it being the only state that is wholly its object. Scarry's speculations then lead her to assert that 'physical pain [...] is an intentional state without an intentional object; imagination is an intentional object without an experienceable intentional state'. ${ }^{35}$ However, Scarry acknowledges that it is most probably an error to state that physical pain in isolation is an intentional state, insofar as only by having an object does it exist as an intentional state. Pain then, in Scarry's formula, only becomes an intentional state 'once it is brought into relation with the objectifying power of the imagination'. ${ }^{36}$ It is through the relation of pain and imagining as 'framing events' in Acker's and Mapplethorpe's work that pain, as an intentional state, is represented and emerges as a (de)creative force. This intentional state is expressed through the language of the body in which meaning and essence are conflated in a performative representational act. 
Acker takes the mythical figure of Eurydice as her narrative voice for her final published text Eurydice in the Underworld (1997). The title immediately reconfigures the original version of the myth, which positions Orpheus as the subject of the tale. Acker appropriates Eurydice's name in the stage directions, shortening it to 'YOU', effectively instating the second person singular as her identity and thus the reader's identity as the narrative voice. This assimilation is important as when Eurydice becomes YOU the reader enters Eurydice's identity, and only through assuming this narrative position can the reader effectively travel as Eurydice into the underworld. For Nicole Cooley, writing about Acker's text, Eurydice's 'status as a mythic icon is subverted by the reality of her suffering body'. ${ }^{37}$ At the outset Eurydice occupies an apartment in Algiers. Like Mapplethorpe's Ajitto, she is dislocated from her classical background and situated in contemporary space. Orpheus, who is 'the spitting image of Hades', is with her. YOU is vomiting, unable to eat and in pain, still bandaged up from her recent mastectomy. The first part of the play details Eurydice's physical pain and diagnosis. Much of the material of this section is taken directly from an article that Acker wrote for the London Guardian Weekend magazine entitled 'The Gift of Disease' (I8 January 1997) in which she detailed her rejection of conventional medicine to treat her breast cancer. She describes the horror of the treatment and the loss of self that she experienced. In the process of being prepared for her mastectomy she recalls: 'I was being reduced to something I couldn't recognise'. ${ }^{8}$ Acker explained: 'conventional cancer treatment was reducing me, quickly, to a body that was only material, to a body without hope and so without will' ${ }^{39}$ Act Three of Requiem also depicts Electra's diagnosis with breast cancer (Electra is synonymous with Eurydice in Acker's work). At the point of diagnosis Electra reports ' $[\mathrm{w}] \mathrm{hat}$ I had believed to be reality/had just been taken away from me'. ${ }^{\circ}$ In the external world of reductive materialism and institutional oppression, Eurydice's pain strips her of identity until she becomes 'the thing under the cap' ${ }^{4 \mathrm{I}}$ in the hospital room. The reductive power of institutional repression that leads to a loss of self within the physical (institutionalized) body is the inversion of the process of bodybuilding in which Acker experiences the physical as self.

Myth allows Acker to bring pain into relation with 'the objectifying power of the imagination' through having Eurydice move into and speak from the underworld. At the end of the eighth scene, YOU goes into the operating theatre/the underworld and leaves Orpheus wandering around 
the hospital grounds, lamenting on the outside, singing: 'Can anyone tell me:/Oh, where is Eurydice?'. ${ }^{42}$ Acker's contemporary equivalent of Eurydice's fatal snakebite, the anaesthetic administered to YOU, provides the means by which Eurydice makes the transition from institutional space to mythological space. Whereas Ovid's tale tells of Orpheus's plight to find Eurydice in the underworld, Acker's play tells the story of Eurydice after the snake bite/anaesthetic. When YOU wakes up she is in the land of the dead. This passage from the external world to the internal world places Eurydice/YOU in the site of her pain and disease, which is inexpressible in the external world. This movement away from the socio-political constraints of institutional space is central in facilitating Acker's representation of pain.

The architecture of Eurydice's imagined space is a mirror of the body. Again it is with reference to Canetti's description of a 'typical house in the geographical labyrinth of Marrakech' that Acker articulates this space in her essay 'Against Ordinary Language'. 'The entire construction of this house', she states, 'windows, etc., is directed inward, to the central courtyard where only openness to the sun exists'. She explains:

Such an architecture is a mirror of the body. When I reduce verbal language to minimal meaning, to repetition, I close the body's outer windows. Meaning approaches breath as I bodybuild, as I begin to move through the body's labyrinths, to meet if only for a second, that which my consciousness ordinarily cannot see. ${ }^{43}$

This internal space of the body becomes textual space in Eurydice. Eurydice's breast cancer places her in an interior space, a non-signifying realm of silence and the imagination that hitherto in Acker's texts has been the site of female desire. In Eurydice this intentional state of pain is the product of the convergence of pain, imagination and textual space. In the section 'Diary Written by Eurydice When She's Dead' Eurydice states: 'Silver here is everywhere an object [...] in this place objects and colours have the same status' ${ }^{44}$ Colour in Acker's work, as in the work of her experimental predecessor William Burroughs, plays an important role as a means to express the impossible and the indefinable. This is seen in an earlier text of Acker's, My Mother: Demonology (1993), which opens:

I'm in love with red. I dream in red.

My nightmares are based on red. Red's the colour of passion, of joy. Red's the colour of all the journeys which are interior, the colour of hidden flesh, of the depths and the recesses of the unconscious. Above all, red is the colour of rage and violence. 45 
The multiplicity of association in the representative power of colour allows Acker in her early work to represent states such as female desire and impossibility that have no set visual objects. Here, in allocating to colour the same representational status as the object, Acker disinherits this object of its primacy and elevates perception. Intentional states are brought into existence via their relation with objects and colours, which in Acker's imagination are coterminous.

Colour functions in Acker's later work as the intentional property by which pain is brought into existence as an intentional state. Colour disrupts the subject-object relationship presupposed in the external world. Derek Jarman used a single colour as a representational device to address the political and perceptual complications of representing pain in his film Blue (I993). Jarman's film realizes the intentional state of his pain through the persistence of the blue screen. This cinematographic device forces his viewer into a position of watching a blue screen for the duration of his narrative. The viewer is absorbed into the otherwise non-signifying presence of the colour blue, which situates her/him both in the pain of Jarman's blindness, his AIDS-related illness, and beyond it. In Jarman's words, 'Blue transcends the solemn geography of human limits' ${ }^{46}$ Colour in this instance acts as the medium through which Jarman communicates the interior of his thought process disallowing any specific image to correspond to his thought, and this connects the interior state of his pain to the viewer's imagination without recourse to sentimentality or polemic. Jarman's blue, like Acker's red, is capable of holding conflict. For whilst 'Blue protects white from innocence/Blue drags black with it/Blue is darkness made visible', ${ }^{47}$ it is also ' $[t]$ he fathomless blue of Bliss'.$^{8}$ Crucially, in his cinematography colour allows Jarman to decontextualize his mind from his physical body. Jarman's use of blue as a representational property within language allows the filmmaker to signify the multiplicity of inexpressible elements within his consciousness. The persistence of blue allows Jarman to narrate his vision against his illness.

A similar narration takes place in Acker's work. Physical pain and imagining occur in Eurydice's underworld in what Scarry terms a 'forward form' that has 'a shape necessitated by the exceptional place that each has within the psychic arrangements of intentional states and their objects'. ${ }^{49}$ The transcendence that takes place in Eurydice's underworld is performative. The text is the object created through Eurydice's speech act from the space of her imagination but in it Eurydice also transcends materiality and it becomes a protean space of creation and transformations: 
I'm a seedling. It's Winter and all the plants are stripped. Whatever of them is able to rise above the earth waves branches in the air.

I am starting from nothing. So slowly.

I can see that the sky is gray today. There's some clarity because the white wall of the empty building. Behind it a derelict red brick building. Blue plastic on a dead-leafcovered roof, over a red door, windows through which nothing can be seen. Two white roses rise out of the small squares of wet soil placed in the concrete.

I see ivy is crawling fungus-like over the nearest roof. There's no more difference between what I'm seeing and who I think I am.

Reality has been reduced.

Somebody said 'nobody reads anymore'. Nobody is anymore. Time is being reduced because plants must spring up. I can see them, roses. I once said 'a rose is my cunt'. I want to do more than just see..$^{\circ}$

The narrative ' $\mathrm{I}$ ' is in a state of becoming. Yet the passage expresses the pain of becoming in a decaying space. As in bodybuilding, Acker breaks down language in this space and this reduction of language to a minimum parallels the reduction of reality. The exiguous use of language and movement towards abstraction, however, produces meaning. In 'Against Ordinary Language' Acker compares the journeying into the body that takes place in bodybuilding to 'that geography that is without the world's languages' found by the man who 'unlearns the world's languages' in Canetti's work. ${ }^{5}$ 'The small loss of language', Acker writes, 'occurs when I journey in and to my own body'..$^{2}$

Rather than a space of corporeality, this internal space has been reconfigured through the use of colour and the reduction of language as a non-objective space, which is found in abstract art. In lines such as '[t]here's some clarity because the white walls of the empty building' Acker can be read as writing against ordinary language. In omitting either the preposition 'of' between 'because' and 'the' or omitting the continuation of the sentence via a verbal clause, Acker both rejects the prepositional relationship of belonging between two entities common to conventional syntax and also the syntactical demand for the continuation of a sentence. The two spaces of ellipsis this creates point to a syntactical disruption and it is within these spaces of absence that Acker's Wittgensteinian language emerges, 'a language game which resists ordinary language'. Eurydice's alienation is expressed in the imagery of the dereliction of the architecture, which parallels the generative elliptical spaces of her language in this scene. In this space the two white roses rise out of the only squares of soil in the concrete. Acker's conflation of the self with perception enacts the symphysis of meaning and essence. 
Erasing the difference between that which she sees and who she thinks she is, Eurydice's writing becomes the language of her body. This space of Eurydice's imagination is an ontological space. Acker's language of the body is performative, as it is, in Judith Butler's terms, 'the vehicle through which ontological effects are established'. Performativity, Butler stated in an interview with Peter Osborne in I994, is something like 'the discursive mode by which ontological effects are installed'..$^{53}$

In the narratives of Eurydice and Electra, Acker explores and exposes the change that takes place in perception with the advent of terminal illness. In 'Requiem' Electra points to what 'we,/mistakenly/call "time"' and the act of 'trying to find meaning where there is none'. Electra narrates a similar movement towards a language of the body to Eurydice's. Although she does not go into the underworld, Acker uses the monologue to have Electra voice an internal narrative, which is cut off from the external world. In her monologue at the beginning of Act Three, she states that at the moment when her disease became unbearable 'thought died in my brain. Something larger than me rose up inside me/and screamed without using my voice,/No more of death. Again/no more of death'. ${ }^{54}$ This silent language that comes from within Electra is important. In Eurydice's narrative she states she wants to do more than just see. In Acker's play, Electra places this ontological birth in the idea of 'acting':

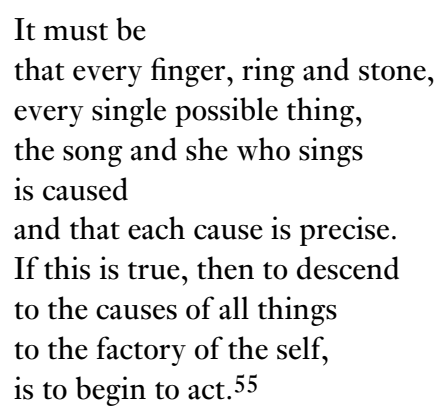

'Act' here is both the performative and for Electra (being the protagonist of a play) the self-reflexive meaning of 'act', as well as the idea of taking action as opposed to remaining passive. The beginning of both is located here in the descent to the 'factory of the self'. There is a clear parallel between Eurydice's imagined space as a result of her descent into the underworld and Electra's descent, which takes place while she is alive. Electra opens her final song with a quotation from Rainer Maria Rilke's first Duino Elegy: 'Who, if I cried out, would hear me among the angels?' 
Electra's final song is a discourse with Rilke in which she moves from fear to an acceptance of death. The idea of the possibility of creation within a space of decreation is articulated by Electra: 'because I have met my death, I give myself birth', ${ }^{6}$ and she fortifies this statement by referring to classical mythology:

\author{
Remember that Persephone \\ raped by Hades \\ then by him brought \\ into the Kingdom of Death \\ there gave birth \\ to Dionysius
}

Acker's reminder of the birth of Dionysius echoes Rilke's idea that grief is the Source of Joy ${ }^{57}$ and that to be full of life is to be full of death. By repeating Rilke's lines within Electra's speech Acker's appropriation of the Electra myth here fuses her protagonist's identity with Rilke. Simultaneously she appropriates Rilke, who was dressed up as a girl by his mother when he was younger, in one of the final instances of that which Carla Harryman has called the 'ventriloquy of childhood' in Acker's work..$^{8}$ In her final lines she banishes the mother/Clytemnestra of the Electra complex and citing Rilke's tenth Duino Elegy Electra sings:

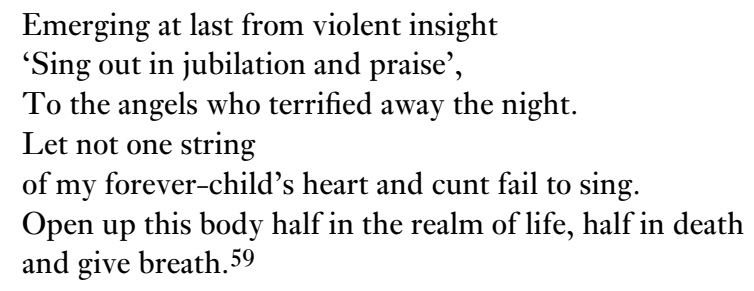

These lines are central to Acker's representation of pain and death and her transcendence of the external world that disallows her becoming. Here the opening of the body within the liminal space between life and death is the space of ontological birth. This is the production of the language of the body in which meaning and essence become one. Echoing Acker's comments on Canetti's beggars, Electra sings: 'For to breathe is always to pray./You language where language goes away.' Electra's falling silent at the end of Requiem is also the birth of her self expressed in a silent language of the body that is created in the absence of ordinary language. 
In his work after I986 Mapplethorpe, like Acker, uses mythology as a way to signify pain as a state outside of reality. Mapplethorpe's representation of pain through his reappropriation of mythology resists and challenges the tendency of critics, observed by Butler in her study of Foucault, to figure the male homosexual 'as one whose desire is somehow structured by death, either as the desire to die or one whose desire is inherently punishable by death (Mapplethorpe)'. Writing in I993, Butler explains that within the 'medico-juridical discourse' that emerged in latetwentieth-century culture 'to manage and reproduce the epidemic of AIDS', 'the juridical and productive forms of power converge to effect a production of the homosexual subject as a bearer of death'. ${ }^{\circ 0}$ To read Mapplethorpe's work in this way, that is, to read the desire and eroticism in his early work as punishable by death and to read his later work as depicting the homosexual subject as a bearer of death, is reductive and unsubstantiable. The eroticism and desire produced in his earlier work are born out of aesthetics. It is in part Mapplethorpe's use of classicism, along with his technical precision, that enables his work aesthetically to both materialize and simultaneously to sublimate radical elements within his reappropriations.

Celant observes that the terminal moment in Mapplethorpe's ouvre in 1986 , when he learnt that he had contracted AIDS, 'carried him to an unknown, beyond time and history'. ${ }^{61}$ His representations of the human body become confined within their oppressive perimeters. This is shown in Mapplethorpe's Thomas series. As in the Ajitto series, Mapplethorpe repeats the classical bodily structure whilst reducing the historical framework to a minimum. Within the new minimal contemporary framework the body exceeds the circumference of the classical art framework yet is trapped within the opaque space. As Jennifer Blessing observes, 'for gay male artists like George Platt Lynes or Robert Mapplethorpe, the classical male nude [...] represents a notion of the ideal that both embodies and expands on its historical antecedents' ${ }^{62}$ This simultaneous embodiment and positive expansion of the male nude is illustrated in the Ajitto series. As Celant has shown, the Thomas series has as its historical antecedents the sixteenth-century plates by Hendrick Goltzius, The Four Disgraces. Thomas embodies in one singular identity all four of Goltzius's fallen classical figures: Ixion, Phaton, Icarus and Tantalus. ${ }^{63}$

Like Ajitto, Thomas is set against a plain background and unlike Goltzius's figure his body is too large for the frame, the structure's 


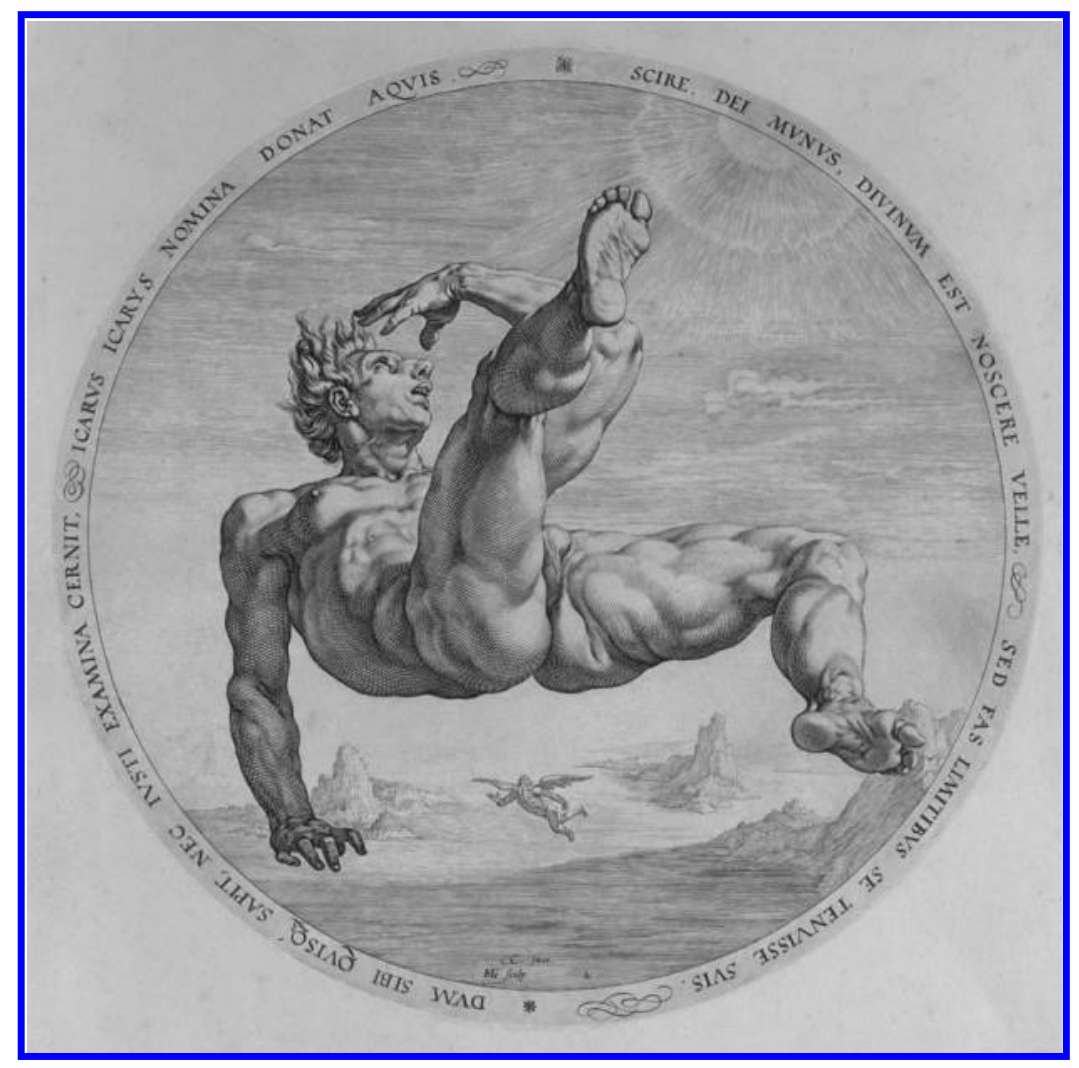

Figure 4. Hendrick Goltzius, 'Ikarus', The Four Disgraces. The State Hermitage Museum, St. Petersburg. ${ }^{64}$

rigid dimensions force the body to contort in classical poses to fit within its perimeters. Crucially Mapplethorpe's Thomas embodies the fallen figures of classical mythology but is unable to expand beyond the framework. In both Ajitto and Thomas Mapplethorpe's appropriations at once desublimate and exceed their classical frames of reference. Yet whilst Ajitto is empowered by reappropriation, Thomas is enslaved. Mapplethorpe does this through reconfiguring the dimensions of the classical physical body into a new contemporary form.

This reduction of the sentient body in Mapplethorpe's later work reaches its negative apotheosis in his transformation of the human body back into the statue. Whereas, in his earlier work, Mapplethorpe made clay flesh, in his later work he shows a movement back from flesh to clay. This movement, Celant argues, 'indicates a physical and corporeal 


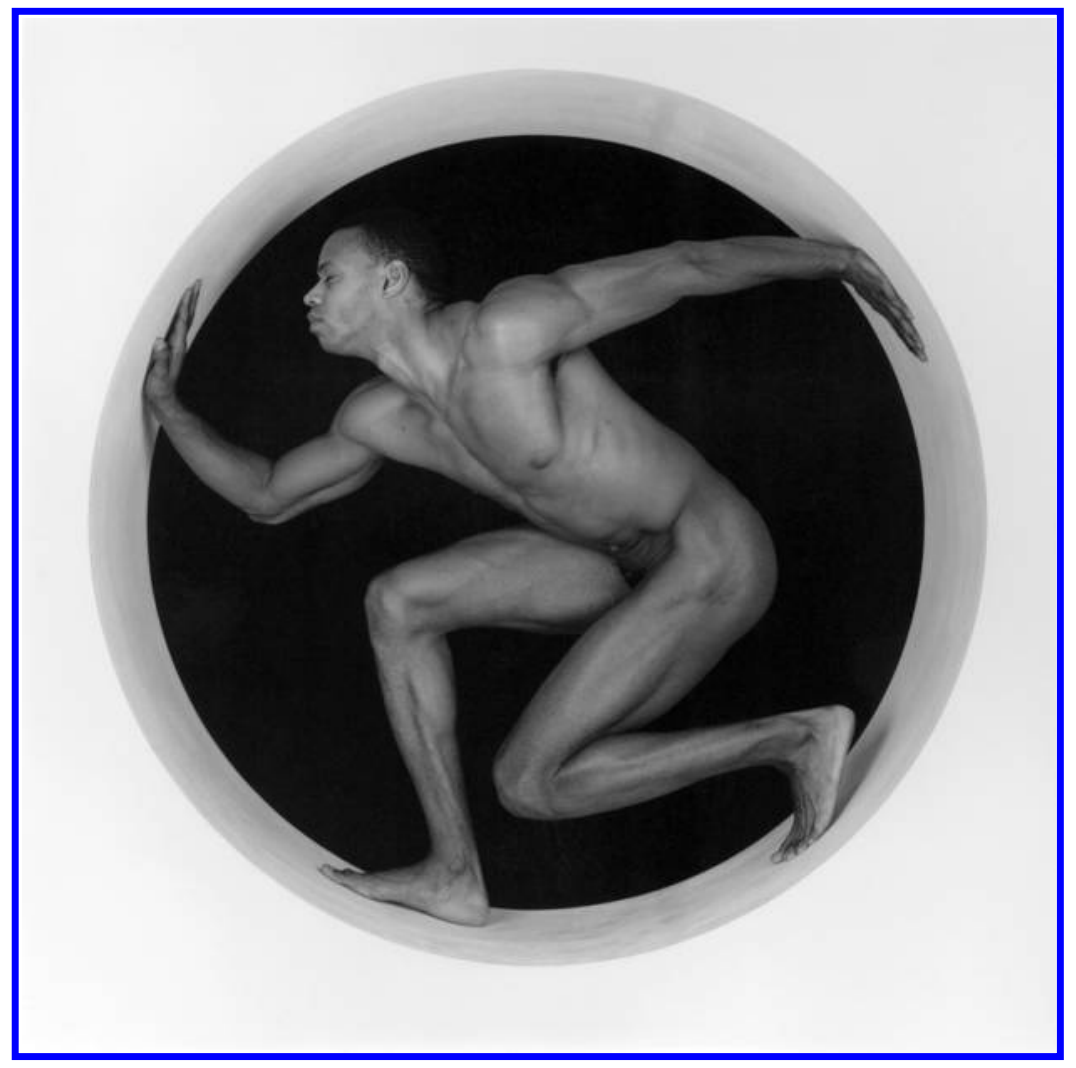

Figure 5. Thomas, I987. C Robert Mapplethorpe Foundation. Used by permission.

condition that becomes non-participatory and crystallized' ${ }^{65}$ Yet whilst Mapplethorpe's work undergoes a transformation towards representing the non-sentient body, his later work is quite the antithesis to the notion of the artist as a bearer of death. In fact he disembodies rather than embodies death and moves into a non-objective abstract space of visual language. Essential to Mapplethorpe's representation of pain and death is precisely the absence of Catholicism (Mapplethorpe had a Catholic upbringing). By adopting classical mythology as his religion Mapplethorpe intentionally rejects the notion of desire as punishable and preserves the humanist aspect found in his earlier work. Rather than representing his desire and aesthetics as sin, Mapplethorpe equates himself with classical figures such as the fallen Icarus, punished only out of the gods' malice and not for any wrongdoing. 
In his later imagery, light and dark play an important role in the material expression of pain through classical mythology. Like Acker, Mapplethorpe's later use of classicism associates his work with the underworld of classical mythology. The figures he uses are either the figures that in mythology died young, such as Antinous or Apollo, or the gods associated with the underworld such as the Roman god Mercury and his Greek counterpart Ermes (Hermes). Mapplethorpe's use of the statue signals a significant move in perception of the body from the sentient to the non-sentient. Divesting the body of its former eroticism, in Mapplethorpe's work there is a parallel reduction of the sentient body to a material body, 'a body without hope and so without will' that Acker perceived conventional cancer treatment reducing her to. Mapplethorpe's movement outside of the body into abstract space in his later work is homologous to Acker's movement into internal space. Both writer and artist move towards the aesthetics of abstraction and the production of a linguistic and visual language of form that is independent from the body.

Mapplethorpe's I986 bust of Mercury is set against a backdrop of venetian blinds, which are almost closed. The horizontal lines that alternate light and dark highlight Mercury's role as a guide of the dead souls to the underworld. Mapplethorpe uses shadow to cast the white marble of the bust in a liminal darkness. The effect of this is to make it ambiguous as to whether light or darkness is being cast from the direction in which Mercury gazes. This is a technique found in many of Mapplethorpe's later images. Here he can be read as using the classical associations of light and darkness found in works such as Müller's sixteenth-century engraving 'The Spirit Separating Light From Darkness' from the series The Creation of the World. These engravings refer to Genesis I: I-5 in which God separates between light and darkness. Mapplethorpe reverses the sixteenth-century representation of the creation of the world in an act of decreation, in which darkness is eclipsing the light. This reversal of creation is mirrored in his method. Mapplethorpe viewed photography as the perfect way to make sculpture, whereas using actual sculptures dispossesses his practice of that creativity. His later work resignifies his earlier photographic practice insofar as the creative act in the photograph takes place around the sculpture, not within it. Thus in his praxis Mapplethorpe effectively moves out of the body into that space which surrounds it. Renegotiating his creative position places Mapplethorpe's reappropriative praxis outside the body so that reappropriation afflicts rather than empowers it. Two examples will serve to illustrate this. 


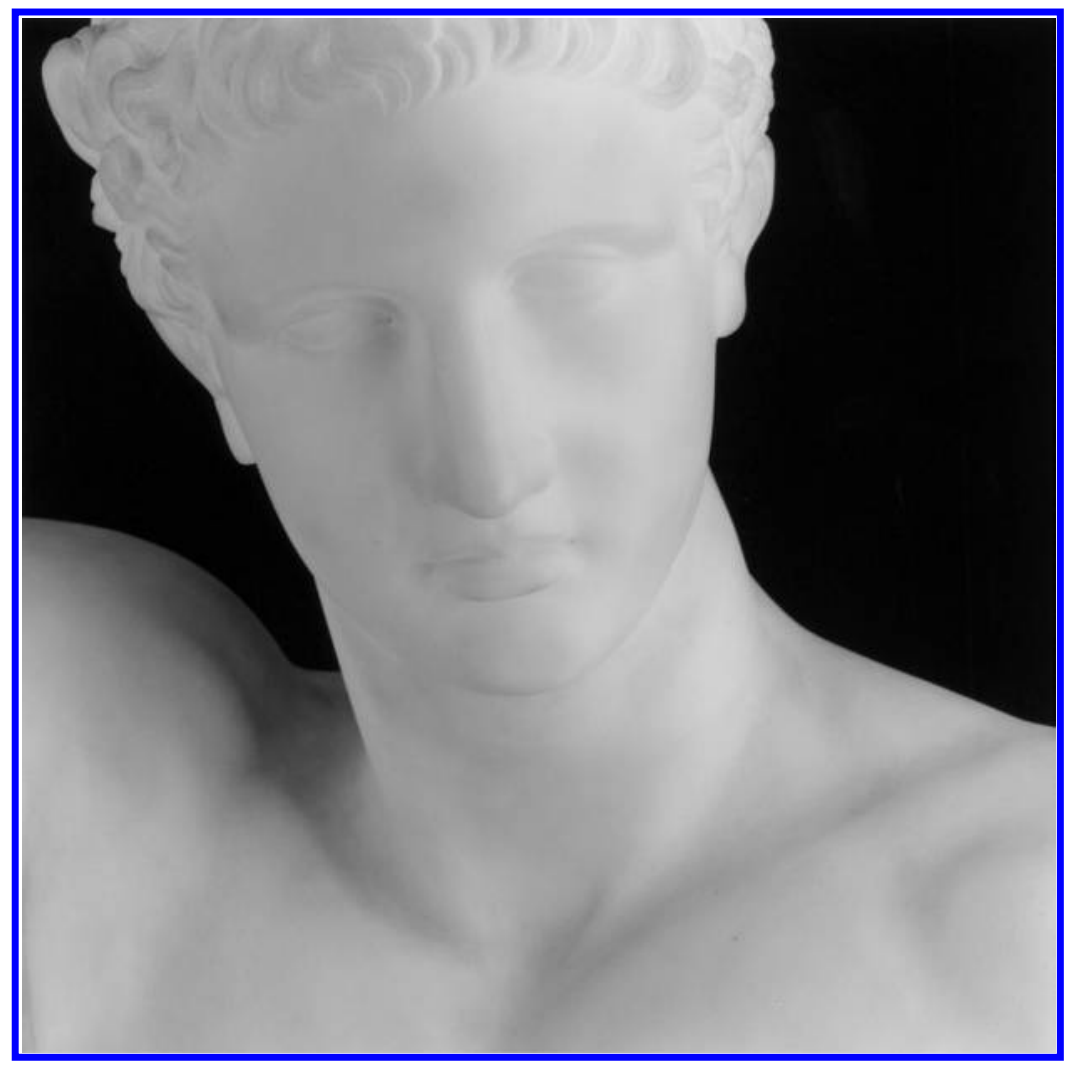

Figure 6. Ermes, I988. C Robert Mapplethorpe Foundation. Used by permission.

In Ermes (1988) the features of the statue are almost entirely obscured, the bright white against the opaque background intensifying the darkness behind it.

The separation between light and dark is absolute in Ermes but it is the dark that is dominant. In reappropriating the separation that takes place in creation in classical mythology Mapplethorpe exposes the sublime nature of the material inexpressibility of the pain of his contemporary condition. His use of the classical statue also testifies to Mapplethorpe's understanding of the ancients' notion of the incompatibility of pain and beauty. As Gotthold Ephraim Lessing observed in 1766 , in his seminal essay on the Laocoon, in works such as Timanthes' painting of the sacrifice of Iphigenia the representation of the father's pain is 'subjected to the first law of art, the law of beauty', ${ }^{66}$ and thereby sacrificed. In his recourse to the statue, Mapplethorpe acknowledges 
the aesthetic impossibility of representing pain in classical sculpture. Lessing applies this to the cause of Laocoon, and says of the sculptor, ' $[\mathrm{t}]$ he master was striving to attain the greatest beauty under the given conditions of bodily pain. Pain, in its disfiguring extreme, was not compatible with beauty, and must therefore be softened. ${ }^{67}$ Thus within the 'necessary limitations' ${ }^{68}$ of sculpture, '[s]creams must be reduced to sighs, $[\ldots]$ because they would often deform the countenance to a repulsive degree'. ${ }^{69}$ Yet, through reappropriation of the art object into the photographic form, Mapplethorpe resists ' $t \mathrm{t}] \mathrm{he}$ softening of the extremity of bodily suffering into a lesser degree of pain'. ${ }^{\circ}$ At the same time as he sublimates the pain of his disease, Mapplethorpe addresses the nature of human creation. The ephemerality of human creation is reflected in the juxtaposition within the photograph of Mapplethorpe's technical precision, the elegance of his figuration and the non-signifying locus of colour. Here Mapplethorpe's distortion of subject-object relations through the use of colour becomes an edifying force that exposes the pain of the unknown and at the same time alludes to the neoclassical recognition of the permanence and continuity of death.

The symbolism of light versus dark, the figuring of a window and classical imagery are again found in Sleeping Cupid (I989). In this later photograph Cupid (Eros), analogically associated with desire (the Latin, cupido) and creativity, has his sleeping face turned towards a perfect small white square window in the right-hand corner of the black background. The figure of sleeping Cupid is associated with the renunciation of worldly pleasures and sexual desire. In Sleeping Cupid the three-dimensionality of the human form is reversed. The sculpture becomes two-dimensional, an image of the human form. The use of the black background renegotiates classical space in a contemporary context. 'Hades' meant 'unseen'. Mapplethorpe reappropriates the dark space of the underworld in the nonsignifying black background of his photographs. Here as elsewhere a separation takes place in Mapplethorpe's later work between the classical body and the essence that once belonged to his contemporary reappropriations of those bodies. The brilliance of that essence which is inseparable from meaning, the silent language of the body which is also the language of the self, is figured in this photograph in the white square, intolerably detached from the marble human form. The act of reappropriation in this picture takes place independently from the human form. Mapplethorpe deprives the classical body of its authority and its representational capacity. 
The Reappropriation of Mythology to Represent Pain

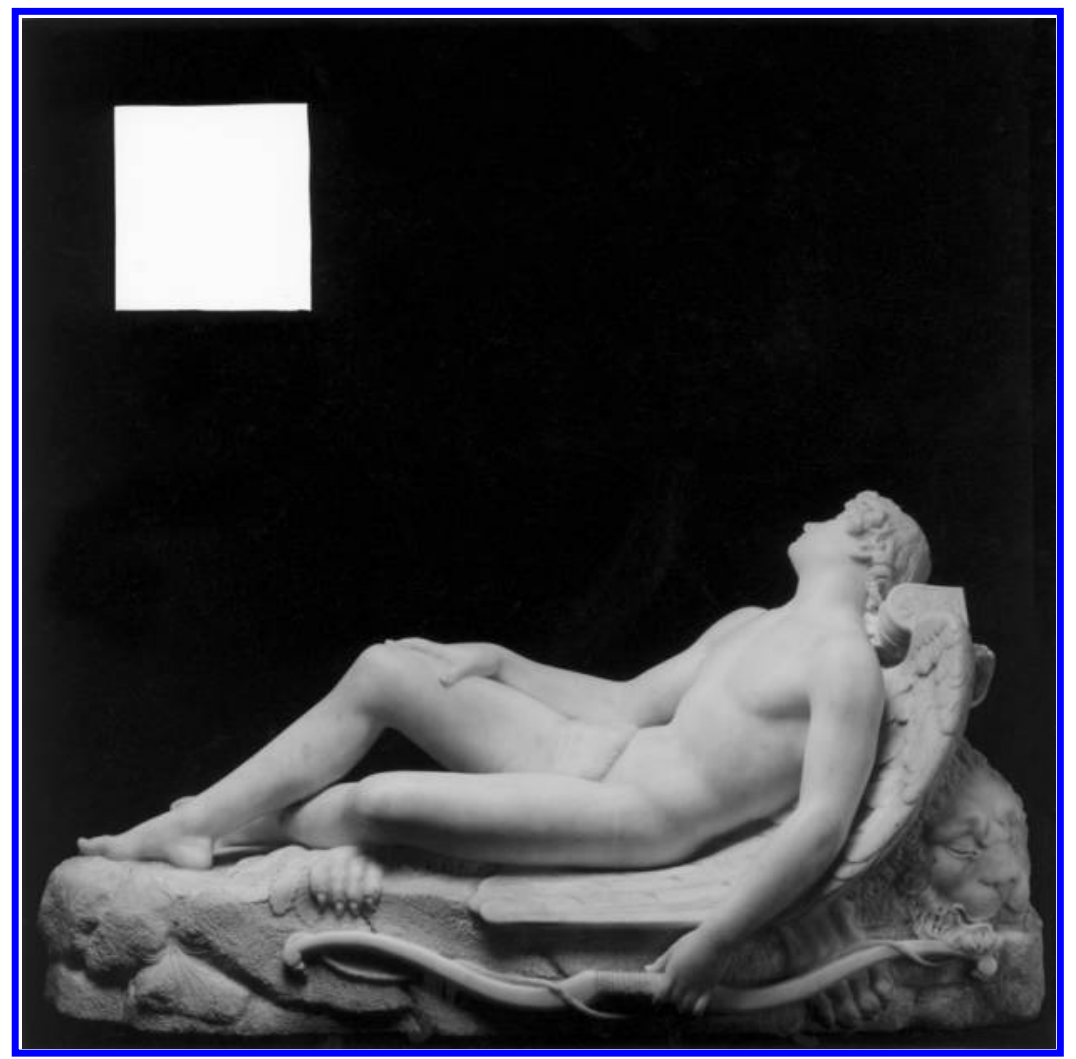

Figure 7. Sleeping Cupid, 1989. (C) Robert Mapplethorpe Foundation. Used by permission.

Instead he alludes in the white square to geometric abstraction and the non-representational composition of works of abstract artists such as Kazimir Malevich's Black Suprematist Square (1913). This detachment is Mapplethorpe's representation of the pain of his disease, which polarizes his body from life and decreates the body. The abstraction of the white square exists independent of visual references to the world, exposing the three-dimensional world as limited and transitory. Pain here is an intentional state that Mapplethorpe brings into existence by uniting it with the intentional property of opacity. The silent language produced in this image speaks of the inevitable destruction of consciousness. Yet crucially the white square simultaneously signals Malevich's fear that art and hence the artist could be 'imprisoned in the cube', ${ }^{71}$ but also 
points to Malevich's other hypothesis, that this 'non-objective creation' 72 might extend into another space that 'extends beyond the circumscribed horizon'. ${ }^{73}$

\section{[RE]PRESENTING PAIN}

It is Acker's and Mapplethorpe's unintentional foregrounding of the state of pain's inexpressibility in their earlier work through the disclosure of the prohibited body that in many ways facilitates their later reappropriations of classical mythology to represent pain. Scarry acknowledges that 'pain and death [...] are radical and absolute, found only at the boundaries they themselves create'. ${ }^{74}$ Here we have an interesting paradox and one that can be linked to the ontological effects of Acker's 'becoming' and Mapplethorpe's opacity. In their early works Acker and Mapplethorpe transgress cultural boundaries, enforcing the body's corporeality and its eroticism as a response to its denial by the external world and liberating it from socio-political constraints. Body breaks through materiality. It is the turning away from this body and celebration of corporeality towards non-sentient representations that allows Acker and Mapplethorpe to invert and reappropriate their own representations, moving towards abstraction and a detachment from the body. This inversion enables them to reveal the radical and absolute nature of pain and death and the boundaries that pain and death create. Their earlier works, through their appropriation of classical mythology, exhibit the process of creation. Through repetition their reappropriations move through the failure of replication to the production of a language in which meaning and essence are one. Their later works are processes of decreating the body. Through the silent language of the body they express the intentional state of pain by bringing it into relation with the self-effacing nature of the imagination. The 'intense form of negation' that Scarry attributes to pain and death is made vivid in Acker's and Mapplethorpe's work. Few artists or writers have been able to expose these boundaries created by pain and death in all their radicalism and absoluteness. It is perhaps in part because Acker and Mapplethorpe exposed the radical essence of sentience in their early work that they succeed in representing, by falling silent, its cessation. 


\section{NOTES}

I Germano Celant, 'The Satyr and the Nymph: Robert Mapplethorpe and His Photography', in Mapplethorpe (Hayward Gallery: Electa, I992), pp. I I-65, this quotation, p. I7.

2 Robert Mapplethorpe, cited in Anne Horton, Robert Mapplethorpe 1986, exhibition catalogue (Berlin: Raab Galerie; Cologne: Kiken-Pauseback, I987).

3 Germano Celant, 'Mapplethorpe as Neoclassicist', in Robert Mapplethorpe and the Classical Tradition: Photograph and Mannerist Prints (New York: Guggenheim

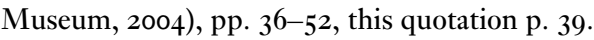

4 Hal Foster, The Return of the Real: The Avant-Garde at the End of the Century (London: The MIT Press, I996), p. x.

5 Ibid., p. 5.

6 Elaine Scarry, The Body in Pain: The Making and Unmaking of the World (New York: Oxford University Press, 1987), p. 3.

7 Ibid.

8 Kathy Acker, 'Against Ordinary Language: The Language of the Body', in Bodies of Work: Essays by Kathy Acker (London: Serpent's Tail, I997), pp. I43-15I, this quotation p. I47.

9 Scarry, The Body in Pain, p. I2.

Iо Ibid., p. I 43 .

I I Ibid.

I2 Acker, 'Against Ordinary Language', p. I45.

I3 Ibid., p. I 46 .

I4 Ibid., p. I I.

I5 Acker, Don Quixote: Which Was a Dream (New York: Grove Press, I986), p. 9.

I6 Ibid., p. го.

I 7 Kathy Acker, Blood and Guts in High School (New York: Grove Press, I976), p. 76

I8 Acker, Don Quixote, p. I64.

I9 Kathy Acker, 'Opera: The Actual Working of Terror and Ecstasy', in The Power of Theatrical Madness (London: Institute of Contemporary Arts, I986), pp. v-vii.

20 Acker, Pussy, King of the Pirates (New York: Grove Press, I996), p. 265.

2 I Ovid, Metamorphoses, translated by Mary M. Innes (London: Penguin, I955), p. $23 \mathrm{I}$.

22 Acker, Pussy, King of the Pirates, p. 265.

23 Ibid.

24 See footnote I.

25 Both Germano Celant and Mike Weaver have written brilliantly and extensively on the similarity between David's The Death of Marat and Mapplethorpe's Fames Ford. See Celant, 'Mapplethorpe as Neoclassicist' (see footnote 3), and Mike Weaver, 'Mapplethorpe's Human Geometry: A Whole Other Realm', in Aperture Iо I (New York) (Winter 1985 ), 43-5I, in particular p. 43.

26 http://en.wikipedia.org/wiki/File:Flandrin,_Hippolyte_\%28 I 805-I 864\%29_Jeune_homme_nu_assis_i 855 _-_Louvre.jpg. Accessed I September 201 I .

27 http://en.wikipedia.org/wiki/File:Gloeden,_Wilhem_von_\%28I856-I93 I\%29__I902_ca_-_Caino.jpg. Accessed I September 20 I I. 
28 http://www.christies.com/LotFinder/lot_details.aspx?intObjectID= 1983739 . Accessed I September 20 I I.

29 Acker, Bodies of Work, p. I46.

30 Ibid.

3I Ibid., p. I45.

32 Ibid., p. 148.

33 Ibid., pp. I48-I 49 .

34 Scarry, The Body In Pain, p. I6r.

35 Ibid., p. I64.

36 Ibid.

37 Nicole Cooley, 'Painful Bodies: Kathy Acker's Last Texts', in We Who Love to Be Astonished: Experimental Women's Writing and Performance Poetics, edited by Laura Hinton and Cynthia Hogue (Tuscaloosa and London: University of Alabama Press, 2002), p. I93.

38 Kathy Acker, 'The Gift of Disease', in The Guardian Weekend Magazine, I 8 January I997.

39 Ibid.

40 Kathy Acker, 'Requiem', in Eurydice in the Underworld, pp. $\mathbf{I}_{5} \mathrm{I}-\mathrm{I} 88$, this quotation p. I8I.

4I Acker, Eurydice, p. I2.

42 Ibid., p. I4

43 Acker, 'Against Ordinary Language: The Language of the Body', p. I 50.

44 Acker, Eurydice in the Underworld, p. I6.

45 Kathy Acker, My Mother: Demonology (New York: Grove Press, I993), p. 7.

46 Derek Jarman, Blue: Text of a Film by Derek Jarman (West Sussex: Littlehampton Printers, I993), p. 7.

47 Ibid., p. I4.

48 Ibid., p. I5.

49 Scarry, The Body in Pain, p. I6r.

50 Acker, Eurydice, p. 16.

5I Acker, 'Against Ordinary Language', p. I47.

52 Ibid.

53 Peter Osborne and Lynne Segal, 'Gender as Performance: An Interview with Judith Butler', in Radical Philosophy 67 (Summer 1994), 32-39.

54 Acker, Requiem, p. I82.

55 Ibid., p. I83.

56 Ibid., p. I 88.

57 Rainer Maria Rilke, 'The Tenth Elegy', in Duino Elegies and Sonnets to Orpheus (New York: Vintage, 2009), pp. 6I-67.

${ }_{5} 8$ Carla Harryman, 'Acker Un-Formed', in Lust For Life: On the Writings of Kathy Acker, edited by Amy Scholder, Carla Harryman and Avital Ronell (London: Verso, 2006), pp. 35-44, this quotation p. 37.

59 Acker, Eurydice in the Underworld, p. I88.

6o Judith Butler, 'Sexual Inversions', in Discourses of Sexuality: From Aristotle to AIDS, edited by Domna C. Stanton (Ann Arbor: University of Michigan Press, I995), pp. $344-362$, this quotation p. 346 .

6r Celant, 'The Satyr and the Nymph', p. 6r. 


\section{The Reappropriation of Mythology to Represent Pain}

62 Jennifer Blessing, 'Classical Allegory in Photography', in Robert Mapplethorpe and the Classical Tradition, pp. 26-35, p. 26.

63 Robert Mapplethorpe and the Classical Tradition, plates 40-48.

64 Photograph (C) The State Hermitage Museum. Photo by Vladimir Terebenin, Leonard Kheifets, Yuri Molodkovets.

65 Celant, 'The Satyr and the Nymph', p. 6r.

66 Gotthold Ephraim Lessing, Laocoon: An Essay on the Limits of Painting and Poetry, translated by Ellen Frothingham (New York: Dover Books, 2005), p. I3.

67 Ibid.

68 Ibid., p. 20.

69 Ibid., p. I 5.

70 Ibid.

7I Kazimir Malevich, 'From Cubism and Futurism to Suprematism: The New Realism In Painting', cited by Anna Moszynska in Abstract Art (London: Thames and Hudson, I990), p. 58.

72 Ibid.

73 Moszynska commenting on Malevich in Abstract Art, p. $5^{8}$.

74 Scarry, 'The Body in Pain', p. 3 I. 